\title{
Usos da ecfrase no gênero histórico seiscentista
}

\author{
The Use of Ekphrasis in the Historical Genre of seventh-century
}

\author{
Eduardo Sinkevisque \\ esinkevisque@hotmail.com \\ Doutor \\ Universidade de São Paulo \\ Rua Pedro Doll, 531/122 - Santana \\ 02404-001 - São Paulo - SP \\ Brasil
}

\section{Resumo}

O artigo discute alguns usos da ecfrase na composição de narrativas históricas do século XVII. Demonstra como letrados seiscentistas atualizam o gênero poético descritivo, entendendo-o como procedimento elocutivo geral. Ao entenderem a ecfrase como descriptio, utilizam-na na descrição/evidenciação de tópicas como as de lugar, pessoa, físico, ações, caráter etc., prescritas por Quintiliano, por exemplo. A técnica amplifica o discurso, fazendo-se, no uso, ornato instrutivo. Particulariza-se a discussão lendo-se um recorte de histórias, de anais, de vidas e de diários das guerras holandesas no Estado do Brasil (1624-1654), cuja visada é retórica. O pressuposto mimético das práticas historiográficas estudadas descarta a leitura realista/naturalista, entendendo-se que a imitação/emulação, no recorte, dá-se, não por meio de realidades empíricas, mas de modelos discursivos/pictóricos. Estudam-se, portanto, gêneros históricos e seus estilos e não os projetos singulares de supostos autores de história.

\section{Palavras-chave}

Escrita da história; Retórica; Estilo.

\begin{abstract}
The article discusses some uses of ekphrasis in the writing of historical narratives of the seventeenth century. It demonstrates how seventeenth-century literati updated the descriptive poetic genre, by perceiving it as general elocutive procedure. By understanding the ekphrasis as descriptio, they use it in the description / illustration of topics such as place, person, physic, actions, character, etc. The technique amplifies the discourse and becomes, in the use, instructive ornate. The discussion is particularized by reading clippings of stories, annals, daily lives and diaries of the Dutch Wars in the State of Brazil (1624-1654). The mimetic assumption of the studied Historiographic practices dismisses the realistic / naturalistic reading by understanding that imitation / emulation, in the clipping, is not done by means of empirical realities, but by narrative / pictorial models. It studies, therefore, their genres and historical styles, instead of singular projects of history authors.
\end{abstract}

\section{Keywords}

History writing; Rhetoric; Style.

Recebido em: 18/3/2013

Aprovado em: 24/4/2013 
E eu escrevo para seus olhos

Gaspar Barléu

\section{Pressupostos}

Ao contrário do que se costuma estudar, ou seja, a ecfrase como gênero específico do discurso ou aplicada a gêneros poéticos variados, ou, ainda, em suas relações com a retórica aristotélica em termos de evidência e prova, demonstra-se, neste artigo, como na elocução do gênero histórico seiscentista a ecfrase é fundamental para a composição da narrativa, sendo exercitada de modos específicos pelo gênero. Ela é formada a partir de descrições e digressões amplificativas, cujo efeito de verdade, e não sua finalidade, é a vivacidade (enargeia) historiográfica, em contrapartida ao que propõem Guinzburg (2010), Strasburger (1978) e Boulay (2012).

Explicar-se-á ecfrase pela explicitação de alguns de seus usos no gênero histórico do século XVII. Particulariza-se a discussão lendo-se um recorte de histórias, de anais, de vidas e de diários ibéricos e holandeses. O pressuposto mimético das práticas discursivas historiográficas em questão descarta a leitura realista/naturalista dos objetos, entendendo-os não como transposições de realidades empíricas, nem como "inspirações de realidades", mas como emulações de modelos retóricos. Nesse sentido, não são examinados projetos singulares de supostos autores de história, mas o gênero e os subgêneros da arte que exercitam e a composição de seus estilos. ${ }^{1}$

A narração/descrição maquinada nos discursos históricos das guerras holandesas (1624-1654) é uma narração (diegese) epidítica, portanto, uma narração dividida e distribuída em partes e não confeccionada como uma unidade fabular localizada em um sítio apenas do discurso. Didaticamente, narram-se/ descrevem-se matérias ao longo do discurso/imagem, temperando-se as cenas com prescrições e comentários próprios do gênero histórico seiscentista. O narrador dos discursos/telas suspende o fio condutor de sua história para justapor digressões argumentativo-exegéticas amplificadoras. Nesse sentido, a descrição é pensada não em oposição à narração, como é hoje, mas como um procedimento que funde fala, visão e audição. Narrar e descrever não se opõem, nem se complementam. Quando se pensa em narrar os feitos construídos como memoráveis e, por isso, exemplares, pensam-se imediatamente esses eventos como evidentia. Relatar e retratar são narrar fazendo ver, extrair para demonstrar, por exemplo, excelência e, por definição, beleza, utilidade. Por meio dessa técnica narrativo-descritiva, as matérias narradas se tornam vistas, não apenas lidas ou ouvidas, sendo entendidas como belas. ${ }^{2}$

Antes de definir "ecfrase" e de explicitar alguns de seus usos no gênero histórico seiscentista, é preciso conceituar "história", definindo-a como um dos gêneros discursivos das Belas Letras do século XVII. Discurso epidítico, de variante encomiástica, a história seiscentista é uma prosa imitativo-emuladora.

\footnotetext{
${ }^{1}$ Cf., a respeito de arte histórica, por exemplo, SPINI (1948); VEGAS (1964) e VIDAL (2009).

2 Segundo a Retórica aristotélica, a descriptio pertence à narratio. Descrever é ação inclusa na narração, definindo-se como enargeia, cujo sentido é fazer ver (ARISTÓTELES, III, XVI).
} 
A Retórica aristotélica trata do gênero epidítico como sinônimo de demonstrativo; seu paradigma é o discurso festivo, em honra de pessoa que deve ser celebrada, predominando a exibição de virtuosismo verbal, com funções encomiásticas de louvor e de censura previstas, as quais têm por tema os atos e as circunstâncias, ao contrário da outra variante do epidítico em que se prescreve o vitupério. 0 gênero epidítico trabalha com a quaestio finita, matéria (discurso) que se refere a pessoas individualizadas e a circunstâncias particulares de tempo e espaço, e com a quaestio infinita, matéria que se refere a uma classe ou personagens típicos e a circunstâncias típicas de tempo e espaço. No epidítico, realiza-se atribuição de caracteres (ethos), a partir de tópicas gerais, quaestio infinita, aplicadas no tratamento de um particular, quaestio finita (ARISTÓTELES, I, 9).

Os modelos da história seiscentista remontam à chamada Idade Média e à Antiguidade greco-romana. Trata-se de um gênero das letras a ser lido por meio da Poética e da Retórica aristotélicas e da Arte Poética de Horácio, pois o discurso se faz in ordo naturalis (HORÁCIO, v. 148), ${ }^{3}$ com elocução na primeira pessoa testemunhal, de um narrador não autor das matérias, mas ponderador, que discorre ou faz arrazoados e juízos a respeito de ações sucedidas a particulares. A testemunha ocular é uma das posições da persona historiador. Ela pode ser fabricada pelo testemunho de outros, por meio da recolha da oralidade ou da leitura das auctoritates do gênero que, entretanto, não deixa de se fazer com a credibilidade da visão. Nesse sentido, ao autorizar o discurso tomando-o por verdadeiro pela voz de outrem não se está abandonando, nem o critério da testemunha, nem o da visão: eles se repõem em variação de elocução. Nesse sentido, não existe o historiador fora do discurso historiográfico seiscentista. Lá, ele é letrado cortesão. No uso do gênero, é um narrador/espectador falando a um leitor/espectador de personagens/atores e de suas ações exemplares e memoráveis, "re-encenáveis". A primeira pessoa produz, no gênero histórico seiscentista, a particularização das ações enunciadas, não como suas, mas de outrem, pois o historiador, como preceitua Aristóteles, "não fará um crime em contar os eventos de uma empresa infeliz e mal concertada, tal como eles se passaram; pois ele não é autor dos mesmos; ele não faz mais do que os narrar." Aristóteles, na Poética preceitua, também, que o historiador, para fazer jus à verdade, a todo o momento insiste em afirmar que narra as coisas apenas de um ponto de vista, o seu, particular, mesmo que segundo relatos de outrem, dos quais diz não ser o autor (ARISTÓTELES, IX, 51b31).

As tópicas de invenção e disposição do gênero, assim como sua narração/ descrição ecfrásica, são pensamentos e argumentos ornados segundo seu fim didático e deleitoso, por isso exemplar.

A ecfrase é, além de um gênero poético descritivo, anterior a Filóstrato, um procedimento elocutivo geral. Entendida como descriptio, é um expediente retórico utilizado na descrição/evidenciação de tópicas como as de lugar, pessoa, físico, ações, caráter. A técnica amplifica o discurso, fazendo-se, no uso, ornato instrutivo. João Adolfo Hansen lembra que 
nos progymnasmata, exercícios preparatórios de oratória escritos por retores gregos entre os séculos I e IV d.C., ekphrasis (de phrazô, "fazer entender", e ek, "até o fim") significa "exposição" ou "descrição", associando-se às técnicas de amplificação de tópicas narrativas, composição de etopéias e exercícios de qualificação de causas deliberativas, judiciais e epidíticas. Aélio Theon diz que ekphrasis é discurso periegético. O termo diégesis sugere a ideia de um percurso, sendo empregado para enunciados narrativos. Como a descrição de ações admite a estrutura temporal quando situa as coisas feitas no passado, a ekphrasis é necessária à prática do gênero histórico [...] que narra em torno - pondo sob os olhos com enargeia, "vividez", o que deve ser mostrado (HANSEN 2007, p. 85, grifos do autor).

A narração do gênero histórico amplifica, na elocução, as tópicas da invenção/disposição por meio de digressões narrativo-descritivo-ecfrásicas. Lembre-se que uma das principais funções elocutivas é a de fornecer, ao texto e à sua recepção, utilidade, prazer e deleite; qualidades, as duas últimas, sem as quais o discurso se torna enfadonho, árido, rasteiro ou pedestre. No decoro adequado ao gênero, à elocução cabe definir o estilo que se mobiliza e, ao mesmo tempo, maravilhar o leitor/ouvinte/espectador com sua fabricação. Portanto, ao estudar as categorias narrativas do gênero histórico no tocante à proferição dos discursos, define-se o estilo do gênero como cosmética epidítica elevada dos lugares.

\section{Escrita para olhos incorpóreos}

Explicitam-se alguns dos usos ecfrásicos ibéricos e holandeses por meio dos exemplos que se seguem:

a) Mas porque de alguma maneira se faria duvidosa a boa opinião de suas letras [...] e virtudes, consentindo em aquela voz, que então se derramou, e eu agora na pureza da história posso expor, mas não justificar, ainda que com digressão, mostrarei parte da causa que pode mover a estes religiosos a não encontrarem por então a queixa popular (MELO 1931, p. 27);

b) Era de mastros que rodeava boa parte do surgidouro, fazendo um arco capacíssimo [...] farei descrição da fábrica desta cadeia; poderá por ventura servir a outros, alguma hora, de remédio [...]. Constava de cento e setenta mastros grossos, que [...], sendo atados fortissimamente, uns a outros, com fortes gumenas e bocas de ferro, ficavam em tal maneira unidos que jogavam facilmente, assim como fazem os fuzis em grilhões das correntes, ou, como em nossas mãos próprias, tem seu movimento os ossos, ligados por benefício dos nervos, que os maneiam juntos e distintos. Todo recinto desta fábrica se afirmava em cinquenta âncoras, que no fundo Ihe serviam de firmíssimo alicerce; estas eram sustidas de amarras grossas, que se tiraram para esse efeito da frota e armazém, mas principalmente da armada de Dunquerque, que nas prevenções a que os náuticos chamam mestrança, a todas as de Espanha fazia grande vantagem. Dez chalupas bem armadas de falconetes, esmerilhões e berços de bronze, Ihe davam contínua guarda de noite; tal era a guarnição de infantaria e diligentes remadores. Destas rondavam cinco por fora, e cinco por dentro do recinto da cadeia, pelo que se fez horrível e defensável ao inimigo. Estava, porém, outra parte sempre despejada, e como porta do muro $[\ldots] ;{ }^{4}$

\footnotetext{
${ }^{4}$ Os itálicos deste e dos demais exemplos são meus.
} 
b') Por esta causa em fábulas e símbolos misteriosos, debuxaram os antigos aos olhos do corpo e espírito, algumas doutrinas de grande utilidade; donde aquela virgem, chamada Ocasião, pintaram com a reversa parte da cabeça despovoada de formosa melena, que diante enriquece e adorna sua fronte; mostrando sabiamente como sempre ficará escarnecido, aquele que topando-se com esta varia donzela, se descuida de a prender pelas primeiras tranças que ela oferece, esperando detê-la pelas últimas;

b") Desta sorte já se via outra que navios queimados, corpos mortos, mar de sangue e fogo, que a fogo e sangue fazia crua guerra aos homens. Outros se rendiam a partido dos vencedores, que abusando da felicidade, tratavam com maior rigor aos que se entregavam, que aos que se defendiam. A morte, em diferentes trajos, assaltava aos tristes combatentes: a uns era de ferro, parecendo no fio das espadas e pontas das picas; a outros de fogo, vendo-se em vida abrasados; a outros de água, afogando a água grande cópia de gente; não poucos de fumo se abrasavam (MELO1931, p. 289-290, 324, 369);

c) Foi El-Rei $D$. João IV de meia estatura, muito gentil-homem antes das bexigas, que Ihe mudaram o primeiro semblante; o cabelo era louro, os olhos azuis, alegres e agradáveis, a barba mais clara que o cabelo, o corpo grosso, mas tão robusto que, se a desordem com que o alimentava o não descompusera, prometia muito maior duração. A pompa dos vestidos desestimava de sorte que fazia gala de trazer os menos alinhados, aplicando grande diligência por que se não alterassem os trajes, nem fossem as outras nações [...] senhoras das vontades de seus vassalos, obrigando-os cada dia com invenções novas a mudarem de opinião. Na conversação foi tão discreto que, não sendo as palavras as mais polidas, usava delas com tal arte, galantaria e agudeza, que parecia fazia estudo do que em outros pudera ser defeito. O entendimento era proporcionado para os negócios grandes; porém, algumas vezes, querendo conseguir o impossível de que todos aplaudissem as suas resoluções, dilatava deliberá-las em prejuízo dos negócios. Compunha-se de tão invencível valor [...]. Foi vencedor em Europa, defendeu-se em África, pelejou na Ásia, triunfou na América. Amou a justiça de sorte que se atreveram os delinquentes a o culpar de severo; mas em muitas ocasiões desmentiu esta opinião com a misericórdia. Nunca passou de liberal a pródigo, e desta virtude tomaram motivo os ambiciosos para divulgarem que fazia tesouro dos cabedais que devia despender, presunção que desvaneceu o pouco dinheiro que deixou. Estimou a música e amou a caça, e em um e outro exercício foi excelente. Venerou de sorte a religião que não perdoou, por estabelecer a Fé e justificar a obediência à Igreja, às diligências mais poderosas. Não teve valido que o governasse, mas deixava-se governar dos Ministros em que reconhecia mais virtuosa direção. Logrou com tanta eminência a prevenção dos futuros, que não houve invasão dos castelhanos, nem invasão dos holandeses, que lhe prejudicasse, e se em algumas ocasiões prevaleceram os Estados contra as suas armas, foi mais culpa dos que governou que do seu governo. E finalmente professou a mais heróica virtude, que foi antepor as leis divinas aos interesses humanos (MENEZES 199 ?, p. 525-526);

d) A terra, estendendo-se, ora em arvoredos, que parece chegam às nuvens; ora em campinas, que fogem aos olhos, sem a cultivarem, é fértil de fruta, caça, e imensas manadas de vacas, tão sem dono, como os bandos de aves, que por sua diferente espécie, e singular formosura, enobrecem o ar, e alegram a vista. Abunda de vários pescados, regada de muitos rios; e acham-se suficientes portos (FREIRE 1977, p. 16-17);

e) E saberei que não há cousa como a honra; e se estas razões vos não demovem, a que pelejando, façais vossa obrigação todos, que homem haverá, que não queira pelejar até morrer pela honra de seu Deus? [...]. Já vejo que com tão alentados soldados vencerei o inimigo; pelejando, 
ganharam vossos passados o que hoje possuem e logram: na guerra não há lugar seguro, nem o terá na paz quem hoje for cobarde! E não vos atemorize o não haver chegado o Camarão e Henrique Dias, que Deus sabe o que faz, porque mais gloriosa ficará vossa ação! Estais muito certos que, quando nos faltam as armas da terra, então nos hão de sobrar as do céu, e os que morrerem por tão justa causa gozarão da bem-aventurança, que assim confio em Deus, pois é a causa sua e vós soldados seus, e os que viverem, ficarão com a glória de haver dado princípio a tal empresa, qual valorosos romanos não intentaram; e lembro-vos ultimamente que para trás não há retirada, logo para diante se há de abrir o caminho a ferro e fogo; e sabei que aquele lugar haveis de ter na paz conforme vos houverdes na guerra (SANTIAGO 1984, II, X);

f) Averiguada coisa é na opinião dos que bem consideram as coisas, que maiores proezas obra para a salvação das almas a pobreza, e desapego dos bens transitórios, em uns Santos, do que em outros a multidão de milagres, e prodígios, e que Deus estime mais a um coração desapegado dos bens da terra, do que a um milagroso. Provo-o com o milagre de Naaman Siro;

f') Sigamos por diante este discurso dos males que consigo traz a ambição, e cobiça, que faz muito ao nosso intento, e mostraremos como a ambição não tem respeito a pai, nem a mãe, nem a parentes, nem a amigos;

$\left.f^{\prime \prime}\right)$ No ano de mil e seiscentos e trinta e cinco chegou à costa do Brasil Dom Fernando Mascarenhas Conde da Torre por Governador, e General de uma grossa armada, para a restauração de Pernambuco, e passando à vista da terra, de sorte que as sentinelas que o inimigo Holandês trazia no mar tiveram vista dela; foi passando para a Bahia, sendo que logo investira com o porto de Olinda, tinha a terra ganhada com pouco trabalho, porquanto os Holandeses estavam descuidados, sem provisão de mantimentos, com pouca gente, e essa espalhada por toda a Capitania, as Fortalezas desmanteladas com as paliçadas por terra, poucas munições, e menos aparelho de guerra, e somente com cinco naus no porto do Arrecife, e essas postas à carga, em véspera de se partirem para a Holanda (CALADO 1987, III, I).

Os exemplos de a) a $\mathbf{f}^{\prime}$ ) podem ser lidos como descrições ecfrásicas e amplificativas do discurso que particularizam pessoas [exs. a) e c)]; fábrica ou máquina [ex. b)]; emblema [ex. b')]; a morte em batalha terrestre [ex. b')]; e lugar [ex. d)], sendo que e), f) e $\mathbf{f}^{\prime}$ ) são digressões patéticas pelo uso de figuras como interrogação e exclamação, em enumeração e acúmulo, e pelo uso de exemplificação bíblica, caso dos enunciados e) e f).

No exemplo b), a fábrica ou máquina é a figura que o discurso faz ver na descrição pela mobilização da metáfora do corpo, pelos ossos e nervos, mas também pela metáfora arquitetônica do alicerce, mediadas por epítetos e comparações, conforme os itálicos acima. Esse tipo de descrição pode ser entendido, como o prescreve Quintiliano, como uma hipotipose, um dos tipos de pintura, primeiro grau do ornato, por ser descrição de objeto. É assim, com efeito, que pode ser lida a descrição do enunciado b') (QUINTILIANO, VIII, CIII).

O enunciado $\mathbf{b}^{\prime}$ ) descreve ecfrasicamente o emblema da ocasião como virgem, como donzela, cuja personificação em comparação com a pintura da figura tem funções morais epidíticas. Inicia a descrição de cima para baixo, pelo eixo ocular que vê primeiro a cabeça calva na parte traseira e povoada de cabelos na dianteira; depois, vê a fronte, o rosto, indicando dois tipos de visão: um corpóreo e outro incorpóreo, ou seja do físico e do espírito. A descrição, 
como pintura, ensina que a ocasião se deve pegar de frente, assim que surgir, pois, uma vez passada, não haverá tranças para segurá-la, como no emblema CXXI de Alciato.

A descrição de morte em guerra do enunciado $\mathbf{b}^{\prime \prime}$ ) faz-se por meio de metáforas como "mar de sangue", da personificação da morte como figura feminina de diferentes trajes, como ferro, fogo e fumo, que são sinédoques ou metonímias das causas instrumentais que levam ao óbito. A disposição desses tropos, por sua vez, propõe anáforas pela repetição simétrica dos enunciados na frase, enumerados "de ferro", "de fogo" e "de fumo". Além desses componentes elocutivos há, ainda, a mobilização de epítetos caracterizadores, como "crua" e "rigor". Observa-se que esse último é substancializado e não adjetivado.

A descrição de pessoa, prosopografia, do trecho c) pinta D. João IV pelo eixo vertical, em que o olho passeia do geral da figura para o particular e minucioso do tipo, indo das qualidades físicas às morais, passando por costumes, hábitos e ações. Nesse sentido, desenha a cabeça, os cabelos, os olhos e a barba e, depois, descendo, o corpo, seus vestidos e modos de alimentação. Na sequência, o modo de conversação do príncipe, sua discrição, polidez e inteligência. Enumera ações bélicas a cargo do governante, passando a elogiar costumes cortesãos, discretos e de prestígio encarnados na figura, finalizando o retrato com a observação de que D. João IV é cumpridor do dever de submeter as leis positivas à lei natural. Embora o narrador mobilize epítetos caracterizadores, como esperado nesse tipo de retrato em prosa, muitas vezes substancializa a adjetivação, com o fim, talvez, de reforçar a substância excelente da alma do príncipe, conforme os itálicos. Ocorre que nessa descrição se pinta o tipo também como etopeia e como antropografia, ou seja, como descrição de caráter e como descrição da figura exterior e o caráter interior do tipo, pois se refere às disposições de ânimo de D. João IV (QUINTILIANO, VIII, CIII).

O enunciado d) é parte de uma descrição da terra do Brasil e, portanto, trata-se de topografia em senso estrito. Mesmo parcial, permite entender modos de exercício da prática. Nele, fica patente que se descreve do geral do lugar para o particular, à semelhança das descrições de pessoa, com o eixo visual de cima para baixo. Nesse sentido, a vista topográfica que se fabrica faz passear o olhar pela figuração do mais amplo para o mais restrito ou minucioso, do terreno a seus habitantes, passando por acidentes geográficos, seus reinos vegetais e animais. Há marcadores discursivos, como conjunções [ora, ora; e, e], que, além de fazerem ligação entre as frases, indicam simetria ou proporcionalidade da variedade e copiosidade que se descrevem ou se pintam. Esses elementos são acompanhados, ainda, de comparações e de epítetos caracterizadores para permitir a eficácia visual, retendo o aprendizado e provocando o deleite pretendidos e esperados.

Vejam-se os exemplos, à semelhança desse uso da narração amplificada por digressões narrativo-descritivo-ecfrásicas, em alguns trechos da prosa de gênero histórico de Barléu, quando a serviço da Companhia das Índias Ocidentais e ao construir o encômio do Conde Maurício de Nassau: 
a) Negue-se a Nassau o seu prêmio - a memória da posteridade - , e esta se entibiará, sucumbindo por causa do silêncio guardado pela inércia dos escritores. Onde tem ela ante os olhos os exemplos dos maiores, cresce com singular emulação e procura imitar com ardor as ações gloriosas que lê. Nada concederei à adulação, cujas causas desprezo, nem tão pouco, por desafeição a ninguém, nada tirarei à verdade, para não ser tachado de inverídico por ódio igual. Quem pretender versar este mesmo assunto para granjear renome [...] e fama $[\ldots]$, ostente a sua eloquência. A mim bastará uma narração singela [...]. Escrevem-se mais livremente os feitos praticados séculos atrás, quando já desapareceram seus autores e testemunhas. Eu, porém, vivo entre aqueles mesmos que obram os atos por mim referidos ou neles_intervieram, e eu escrevo para os seus olhos. Aos documentos públicos dou o crédito que lhes dão os amigos da verdade, e não desejo para mim crédito maior: relato aqui, não o que viram vagamente os olhos, mas o que escreveram, durante a paz, espíritos serenos e acalmados. Farei uma seleção no enorme acervo dos fatos e nos numerosos maços de documentos para evitar aos curiosos destes assuntos a fadiga de uma longa indagação [...]. Antes de entrar no meu assunto, devo recordar o que é e como é o Brasil, qual foi, nessa época, o estado da nossa República e do nosso exército, quais as vantagens e desvantagens nossas e do inimigo, quais os intentos da Companhia e do espanhol;

a') Recife é a principal sede do governo, do comércio e da guerra, e também rica despenseiro de armas, abastecimento e mercadorias. Da banda que entesta com Olinda, tem diante de si dois baluartes em forma de obras cornutas, um de pedra, olhando para o mar e para o porto, outro de terra, pondo para o rio. Une-os uma cortina que corre entre os dois, defendida por uma paliçada. No meio dela abre-se uma porta para dar passagem aos que saem de Recife ou nele entram. O baluarte de pedra protege-se com sete peças de bronze; o de terra, provido de cinco peças de bronze e duas de ferro, serve para segurança do interior da costa e do exterior do porto;

a") O palácio por ele [Nassau] construído (chama-se 'Friburgo', isto é, cidadela da liberdade) tem duas torres elevadas, surgindo do meio do parque, visíveis desde o mar, a uma distância de seis a sete milhas, e servem de faróis aos navegantes. Uma delas, tendo no topo uma lanterna e jorrando sua luz nos olhos dos nautas, atrai-Ihes a vista para si e para o forte da costa, indicando-Ihes a entrada segura e certa do porto. De cima delas descortinam-se, de um lado, as planícies do continente e, de outro, a vastidão dos mares, com os navios aparecendo desde longe. Idôneas para atalaia e para se vigiarem de dia os salteadores, ainda por esta serventia merecem o gabar-se-Ihes a beleza e necessidade;

a'") Houve então a primeira caça de um animal bravio chamado pelos índios tatu e por nós armadilho. Mais atrás fiz menção dele. Descreve-o minuciosamente Francisco Ximenes. É, diz ele, animal extraordinário, do tamanho de um cãozinho de Malta, mas de cauda maior, com as patas como as do ouriço: as dianteiras com quatro dedos e as traseiras com cinco. O focinho tem o mesmo feitio, porém é mais comprido e mais fino. As orelhas são cartilaginosas e sem pelos. Apresenta o corpo inteiro, menos no ventre, e em redor do pescoço, coberto de escamas, como as de um cavalo revestido de armadura. Elas se reúnem por meio de certos tendões, de modo que ele se pode mover facilmente em todas as partes. Essas escamas são inteiramente ósseas [...];

a"'") Além disso, o Conde [Nassau] enriqueceu e ornou com edifícios vilas e cidades. Construiu pontes e palácios para utilidade e beleza. Erigiu, em parte por sua munificência, um templo para a piedade e para o serviço divino. Teve consigo e favoreceu, na paz e na guerra, os mais eminentes artistas: arquitetos, geógrafos, pintores, escultores para que eles mostrassem, vencidos, aos holandeses de além-mar os lugares, as 
terras e as cidades que ele próprio vencesse. Julgava legítimo que o cultivo do engenho deveria acompanhar o império aonde ele fosse. Mandou desenhar cartas geográficas com grande cuidado e a sua custa, nas quais se representavam as cidades, vilas, povoações, fortalezas, currais, lagoas, fontes, cabos, estâncias navais, portos, rios, escolhos, engenhos, igrejas, conventos, plantações, posição das regiões, suas longitudes e latitudes e outras cousas, sendo autor delas Jorge Marcgrave, exímio geógrafo e astrônomo, o qual, incumbido de fazer o mesmo na África, lá morreu. Para agradar-Ihe mandou o Conde construir numa eminência um observatório, onde se estudassem os movimentos, o nascer, o ocaso, a grandeza, a distância e outras cousas referentes aos astros. A estes estudos juntou ainda aquela diligência com que fez desenhar e pintar artisticamente os animais de várias espécies, as maravilhosas formas dos quadrúpedes, assim como das aves, peixes, plantas, serpentes e insetos, os trajes exóticos e as armas dos povos (BARLÉU 1974, p. 20-21, 141$142,151-152,228,346-347)$.

Há, nos enunciados acima, quatro tipos de descrição: uma de cidade, outra de palácio, uma terceira de animal e uma quarta de pessoa [exs. a'), a'), $\left.\mathbf{a}^{\prime \prime \prime}\right)$ e $\left.\mathbf{a}^{\prime \prime \prime \prime}\right)$ ]. A cidade do Recife é vista pelo elogio de suas riquezas, funções e utilidades, em primeiro lugar. Depois, pelo seu poderio defensivo bélico, também como passeio panorâmico, do mais geral para o particular, como em muitos casos discursivos ibéricos. O palácio Friburgo, ou Das Torres, nomeado por antonomásia e por sinédoque, é descrito como figura em meio à topografia que - ladeia, inclusive seu jardim. A narrativa convida o leitor a passear, primeiro pela visão de longe, do mar, depois, aproximando-se mais. Caracterizam-na epítetos que são adjetivos substancializados em beleza e utilidade. Por sua vez, o tatu descrito por Barléu é visto em seu aspecto geral para, somente depois, ser apresentado em seus aspectos particularizantes, mais minuciosos. O principal procedimento, nessa descrição, pode ser pensado, no entanto, como o uso de elementos comparativos com o repertório de conhecimento já adquirido pelos interlocutores do discurso. Assim, compara-se o animal referido com outros do conhecimento partilhado e de suas características, sendo apresentado como um "cãozinho de malta", por exemplo, ou um "cavalo revestido de armadura".

O último tipo de descrição aqui selecionado refere-se às ações do Conde Maurício de Nassau [ex. a'"')]. Pensa-se que a pintura discursiva que mais chama a atenção, no enunciado, é a que se faz por meio de dois tipos de enumerações: primeiro, de artífices privilegiados do conde e, segundo, dos objetos de estudo dos trabalhos desses artífices e de suas utilidades.

Essas descrições, tanto as do mundo católico ibérico quanto as do mundo calvinista holandês, podem ser pensadas como enargeia ou evidentia, ou representações que visam à clareza do discurso, representando as coisas da invenção como se fossem vistas. Objetos, pessoas, figuras exteriores e caracteres de pessoas são vistos e não apenas lidos ou ouvidos. São colocados aos olhos do intelecto e, portanto, aos olhos incorpóreos da recepção. São vivacidades, figuras e não tropos, que funcionam também, ao lado das semelhanças, comparações, bosquejos e ênfases, como provas. São vivacidades pintadas por meio das palavras, como se fossem quadros (QUINTILIANO VIII, CIII). 
Em relação às afinidades elocutivas entre os discursos de gênero histórico de variante anais quanto ao uso de amplificações e digressões ecfrásicas, incluem-se, aqui, dois exemplos:

a) Começaram as baterias da nossa artilharia, dos quartéis do Carmo, São Bento, Palmeiras, e praia, com tanta fúria, e continuação, quanto era nos nossos o desejo de resolver a empresa em breves dias. Era notável o dano que o inimigo recebia, de tão continuadas tormentas de fogo, e chuveiros de balas, sobre a cidade, e navios do inimigo (GUERREIRO 1966, p. 69);

b) antes de continuarmos a narração dos feitos no Brasil, começaremos dando uma descrição da [...] Paraíba (LAET 199?, p. 83).

O enunciado a) é parte de uma descrição de batalha, descrição de ações e, portanto, é uma hipotipose. O b) indica que o narrador fará uma descrição de lugar, portanto uma topografia, que não se transcreveu por brevidade.

Escolheram-se cinco exemplos em que se explicitam os modos narrativo-descritivos amplificados e ornados em extratos de vidas. Os exemplos funcionam como descrição amplificadora ornada por epítetos, enumerações, figuras patéticas etc.:

a) Há neste sujeito [João Fernandes Vieira] grandes cousas para o governo de uma república: na guerra é muito previsto, grande disposição e valor liberal de sua fazenda, e bem se tem experimentado isto nas guerras de Pernambuco [...] ciência na milícia, esforço e valentia, autoridade para mandar e governar, felicidade e ventura para alcançar vitórias, e empreender grandiosos feitos nas armas. É muito visto em razões de Estado; na política é geral e judicial, e sobretudo é dotado de todas as particularidades que são necessárias a um homem para viver no mundo. De outras muitas outras cousas deste varão insigne pudera fazer largo, difuso e encomiástico panegírico, que por brevidade deixo, e somente escrevo o mais essencial, para que se veja, que estando em meio de todas estas bonanças e prosperidades, sendo senhor absoluto [...] arriscando sua vida e estando grandioso somente por zelo da honra de Deus [...] e em segundo lugar, por livrar o miserável povo de tantas tiranias, injustiças, roubos, homicídios, ignomínias e insolências, quantas têm usado os holandeses;

$\left.a^{\prime}\right)$ Quem vira o mestre de campo João Fernandes Vieira naquele conflito e pendência, assim a pé como a cavalo, posto em frente e diantera de todos os seus soldados, animando-os, exortando-os a romper os sete esquadrões do inimigo, que com tanta mosquetaria e chuçaria defendia aquele boqueirão e com peças de artilharia lhe davam cargas, sem reparar no grande perigo que sua vida corria, posto na parte mais arriscada, fazendo maravilhas com sua espada, como leão forte, a uns vai ferindo, a outros na fuga Ihes dá caça, os que alcança, fere, discorrendo por entre a multidão da gente holandesa, com seus valentes capitães e soldados, partindo, destroçando, cortando, ficando o campo tinto em sangue, quão admirado ficaria? [...]. Que um sujeito sem reparar em tão grande e manifesto risco e empenho de sua vida, de que dependíamos tantos, investisse como leão sem consideração de tanto perigo diante de seus soldados, contra sete esquadrões tão fortes do inimigo, cercados de chuçaria, tão perto de sua mosquetaria e artilharia, indo sempre para diante até lhe ganhar o posto e destruir os esquadrões holandeses, não se lhe dando das imensas balas que choviam? Se não fora este sucesso tão patente e manifesto, e sucedera nas últimas e remotas partes do 
mundo, pudera recear o cronista de escrevê-lo [...]. Se Quinto Cúrsio louva e engrandece tanto Alexandre Magno, porque em uma batalha com os persas posto em frente de seus soldados, pelejando com a espada e rodela embraçada, na qual recebeu as setas que os inimigos contra ele disparavam, ficando crivada e cheia delas, veja-se que diferença, há, e que comparação de Alexandre em aguardar as setas e quão superior ficou o mestre de campo João Fernandes Vieira, porque a peito descoberto não aguardou nem esperou setes senão balas de artilharia e mosquetaria, e sem rodela nem outras armas defensivas mais que seu valoroso peito e animoso coração, que tanta superioridade tem a todos os demais? E é para admirar que no meio da pendência, quando mais furiosa e sanguinolenta estava no boqueirão, chegando perto do inimigo, disse em voz alta: "Ah! Flamengos, rendei-vos que aqui está João Fernandes Vieira, que é vosso açoite!" (SANTIAGO 1984, p. 179-180, 548-549).

No trecho a), descreve-se e constrói-se o ethos de João Fernandes Vieira, mobilizando-se uma etopeia feita por meio de pares de qualidades coordenadas e proporcionais. Usam-se também epítetos substancializados e enumerações de ações do militar, indicando, então, que, além da etopeia, o discurso se fabrica por hipotipose. Os dois tipos de descrição, como pinturas de história, de subgênero retrato, vivificam o herói, propondo-o aos olhos e aos ouvidos do receptor. Nesse exemplo, a descrição não se faz por elementos corporais, de traços ou linhas físicas da persona, como no caso da descrição acima de D. João IV, que, inclusive, mescla, como antropografia, aspectos físicos e éticomorais. No trecho $\mathbf{a}^{\prime}$ ) têm-se a etopeia e a hipotipose, por se descrever e constituir o ethos e as ações da persona João Fernandes Vieira. Chamam a atenção, ainda, usos de enumerações, comparações, metáforas e de figuras patéticas interrogativas e exclamativas. Nota-se que o primeiro fragmento da vida do herói está disposto em um capítulo intitulado "Breve discurso da vida...", enquanto que o segundo fragmento respeita o decoro narrativo-descritivo de batalhas e, por isso, privilegia as ações. Além disso, fica patente que o encômio se aloca em sítios diversos ao longo do discurso, como convém a uma prosa de gênero didático, demonstrativo-deliberativa.

Os dois exemplos de fragmentos de vidas explicitados acima podem ser contrastados com outros três, relativos a usos holandeses do gênero, como pode ser observado:

b) desejoso de comunicar ao público esta parte da história do nosso século, que me pareceu considerável e bastante pouco conhecida, acreditei ser esta obra, fruto principal de minhas viagens, um tributo legitimamente devido a V. Alteza, não devendo ser publicada antes de Ihe ter sido oferecida. Mas não é unicamente ao cargo de almirante que eu quero prestar esta homenagem, pois a situação eminente que V. Alteza ocupa no Estado, o brilho de seu ilustre nascimento, devido às virtudes heróicas do maior dos nossos monarcas, as quais revivem tão gloriosamente na sua pessoa, tornando-a tão cara e tão admirável a toda a França, exigem de todos os franceses os testemunhos honoríficos imagináveis. Sou de uma província que, além desta estima e afeição universais, deve a V. Alteza culto especial e reconhecimento extraordinário, possuindo particular conhecimento destas virtudes pela feliz prova enfrentada quando mereceu a honra de tê-lo por governador (MOREAU 1979, p. 15); c) Mas um general vigilante, moderado e prudente, assim como pode 
tolerar os paroleiros batavos, assim também sabe precatar-se de empreender ações superiores às suas forças, onde faltam abastecimento, reforços, dinheiro. A expectação pública é em verdade impaciente dos resultados, se bem seja a dos particulares loquaz mais entre os imperitos de tais assuntos. Maurício, sem importar-se com esses, seguindo seu próprio parecer ou o dos seus, firmado em grandes exemplos e não na opinião do vulgo ou nas vacilantes e levianas considerações dos que estavam de longe, praticou, num mundo bárbaro, durante a paz e a guerra, entre inimigos ocultos ou declarados, na terra e no mar, feitos digníssimos do seu século, gloriosos às Províncias-Unidas, aos Nassaus e a ele próprio e úteis à Companhia. Portanto, se quisermos emitir juízo verdadeiro, afirmaremos que não foi dado ao Conde o governo do Brasil, mas sim o Conde àquele governo, e a ninguém, senão aos inimigos, pode pesar de haver sido o Brasil administrado por ele (BARLÉU 1974, p. 350); d) Aqui também estava outro capitão chamado Arciszewski, um polaco, que igualmente, no primeiro desembarque dos holandeses, era capitão, \& havendo sido repatriado uma vez para a Holanda, aprouve aos senhores da Companhia das Índias Ocidentais, constatando suas habilidades, empregá-lo aqui novamente como coronel. Ele posteriormente demonstrou ser uma coluna-mestra de seu Conselho, sendo um homem de experiência tanto em anos quanto como uma pessoa própria em todas as ocasiões. Era um prudente comissário da Companhia, muito político e previdente. Cuidadoso, homem apropriado para os serviços do exército. Também muito temperado e estrito na execução das ordens. Apesar de punir com mão pesada as transgressões, sem respeitar a qualidade dos ofensores, tanto oficiais como soldados, era igualmente, pelo contrário, afeito a recompensar os merecimentos dos homens por inteiro. Desse modo sua palavra era lei para nós. Em resumo, o que ele tentava conseguia, sempre pretendendo fazer algo com bom aconselhamento, pesando tanto as conveniências como as inconveniências. Alguém como ele não mais existiu nem antes nem depois da conquista desta terra. Era um homem religioso, nunca deixando de levar o exército à batalha sem orações, não importando a pressa, nem o socorro que tinha que levar, isto devia ser feito, para que Deus desse bênção a todos seus esforços e ações. É verdade que o governador era um bravo soldado, e muito próspero, mas era ainda um homem jovem, muito apressado \& sangrento nas execuções. Entretanto, sua sabedoria ensinava-o a ser aconselhado por Arciszewski em todos os assuntos do exército, esperando que os frutos disso se refletissem sobre sua própria honra, sendo ele chefe (PUDSEY 2000, p. 73).

Dos enunciados acima, extrai-se o entendimento de três tipos de pinturas de história, isto é, três tipos de ornatos de primeiro grau: em b), tem-se uma hipotipose; em c), uma etopeia; e em d), uma antropografia, conforme os itálicos de epítetos substantivados ou substancializados ou de substâncias adjetivadas. Na antropografia do último exemplo, o letrado enumera qualidades em tríade, depois em dístico, substancializando os epítetos de pessoa, conforme os itálicos.

Nos diários, a narração se faz também amplificada por meio de digressões descritivas e ecfrásicas como nos outros subgêneros discursivos históricos, como se vê nos dois exemplos do recorte ibérico e nos cinco do recorte holandês:

a) Resolveu o general enviar logo em seu socorro o mesmo que de lá trouxera Matias de Albuquerque Maranhão, e ordem para que de caminho (pois ficava nele) soubessem se o inimigo tentava tomar a ilha de 
Itamaracá, e que, no caso afirmativo, passassem a socorrê-la. Assim aconteceu. Está aquela ilha em 70 e $2 / 3$ da linha equinoxial para o sul, e a 7 léguas ao norte da vila de Olinda; forma-a um braço de mar que a cerca, tendo ele de largo um tiro de mosquete, e fazendo duas barras; uma serve para entrar e é a principal, outra para sair, a qual chamam Catuama; esta suporta barcos, e a outra navios de 200 toneladas. Aqui desembarcou o inimigo pela parte do norte, porque a do sul era já terra de Pernambuco, de que este braço de mar a separa, recebendo ai o rio de Santa Cruz. Havia uma légua acima a vila de Igaraçú, uma das de Pernambuco. Tem a ilha dez léguas de circunferência;

$\mathbf{a}^{\prime}$ ) Desejando Matias de Albuquerque ir nelas embarcado, por evitar as fadigas de uma viagem por terra de mais de cem léguas, não o pode conseguir pela precipitação com que saíram. Com isto houve de partir a 16 de dezembro; e a julgar pelas gerais demonstrações de sentimentos que neste dia apareceram, podia ele com razão dar por bem empregados tantos trabalhos e privações que nesta guerra suportou pelo decurso de seis anos, nos quais procedeu do modo que se pode inferir nesta leitura destas Memórias e conforme se vê de vários documentos, que de certo merecem mais fé que os êmulos e inimigos, os quais nisto o foram mais capitais do serviço del-rei que os próprios Holandeses; porque negando aqueles a verdade, estas a confessavam dizendo constantemente que enquanto Matias de Albuquerque Ihes fez a guerra com esses poucos meios que possuía, Ihes fizera perder mais de dezesseis mil homens, sem poupar sua pessoa aos maiores perigos nas ocasiões em que o conde de Bagnuolo e outros Ihe faziam protestos sobre o risco a que expunha tudo expondo-se tanto a si; julgando dificultoso achar quem o suprisse, se ele chegasse a faltar [...]. São tantos os motivos de louvor e inveja, que por muitos os omito, certo de que não deixarão de publicá-los os que os presenciaram. De seu desinteresse e probidade dou por testemunhas os seus próprios inimigos [...]. Se houver quem culpe esta digressão, responderei que se tivesse assistido e visto o que eu vi, de certo que arguiria de abreviador, mas, seja como for, entendo que a verdade e a minha modéstia bastarão a desculpar. Acabou finalmente Matias de Albuquerque o seu governo e sigamos a falar no que depois aconteceu [...]. O mestre de campo general D. Luiz de Roxas e Borjas começou a trabalhar com grandíssimo zelo e cuidado (COELHO 1944, p. 53, 221);

b) No dia 4, ao raiar do dia, com tempo claríssimo, avistamos a ilha de Penedo ou São Paulo, como é chamada pelos portugueses. Vista à distância, dá a impressão de uma grande vela, para depois, à medida que a gente se aproxima, ir se transformando em cinco altos rochedos;

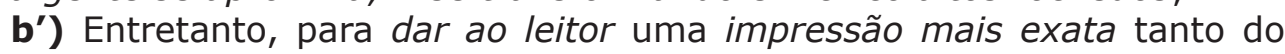
Recife como da situação da Cidade Maurícia, é preciso que se diga que toda a costa do Brasil, de um extremo a outro, é guarnecida por uma longa e espessa franja de rochedos rasos que, n'alguns pontos, chegam a ter 10 a 20 e, n'alguns lugares, 30 passos de largura;

b") Na parte da ilha, que fica entre os rios Capibaribe e Beberibe e entre o forte Ernesto e o forte triangular de Waerdenburgh, encontravam-se os já citados jardins do Conde Maurício, providos de todas as variedades de plantas, frutas, flores e verduras que a Europa, a África ou ambas as Índias poderiam proporcionar. Havia lá cerca de 700 coqueiros de todos os tamanhos; alguns deles com 30, 40 e 50 pés de altura, que estavam a cerca de 3 e 4 milhas, deram frutos já no primeiro ano. Viam-se ainda nesses jardins, cerca de 50 limoeiros, 18 cidreiras, 80 romeiras e 66 figueiras. [...] No centro do Jardim erguia-se a residência do Conde, chamada Friburgo. Edifício de aspecto nobre que, ao que se diz, custou 600.000 florins. Oferecia uma perspectiva admirável, tanto do mar como de terra e suas duas torres eram tão altas que podiam ser vistas do mar a 5 ou 6 milhas de distância, servindo de baliza aos marinheiros. Em frente à casa havia uma bateria de mármore que se elevava do rio, em degraus 
e sobre a qual estavam montados 10 canhões para a defesa do estuário. A 2 ou 3 pés da corrente, viam-se grandes tanques d'água doce no jardim, não obstante a do rio, em toda a redondeza, ser inteiramente salgada. Além desses, havia viveiros repletos de todas as qualidades de peixe. [...] Bem ao pé da ponte que franqueia o rio Capibaribe da Cidade Maurícia ao continente, o Conde Maurício mandou construir uma agradabilíssima residência de verão a que os portugueses denominaram "Boa Vista". Era rodeada de aprazíveis jardins e lagos de peixes que também serviam de baluarte para a defesa da ilha de Antônio Vaz e da Cidade Maurícia (NIEUHOF 1981, p. 26, 40, 45-46);

c) Este país está situado 8 graus além da Linha Equinocial. Um país habitado desde o início por selvagens. Quão longa foi sua permanência é impossível dizer, pois nada há nas tradições dos selvagens, em razão de sua ignorância [...]. Os tapuias são imensos de estatura, e uma gente extraordinariamente ativa e forte;

c') E dentro de um porto seguro e espaçoso onde se encontra com um agradável riozinho, vai-se para uma cidade chamada Olinda. Uma cidade famosa por sua curiosa situação, de uma prazerosa perspectiva, com edifícios suntuosos, acompanhados por raros jardins com frutas e prazeres, fontes de uma água pura maravilhosa. Esta cidade está colocada sobre a encosta de uma colina, inclinando-se com todo seu brilho para o mar, e do outro lado o seletíssimo lugar do resto da região. Ao pé da colina em direção ao mar foi construído um reduto de pedra com artilharia e na subida da colina, em duas diferentes passagens foram postos dois fortes com artilharia e como os conventos estão postos na parte mais alta da cidade foram feitas baterias para secundar os fortes inferiores. Estes conventos, sendo edifícios bastante espaçosos, embelezaram muitíssimo a cidade. Este lugar dista do recife cerca de uma légua, ficando em direção ao norte. Neste lugar houve a afluência dos mais galantes homens e mulheres, cada qual esforçando-se por ultrapassar os outros em orgulho e grandeza, tanto quanto as mulheres, por sua parte, podiam fazer. Elas não economizaram tesouro algum para enfeitar-se, para enfeitiçar o coração de seus amantes com suas belezas, tendo à mão a ajuda de perfumes odoríferos. Neste lugar eram comuns todos os cuidados com as mais raras coisas que mesmo na Europa são difíceis de obter. Nesta cidade as classes de mulheres mais elegantes usavam, em lugar de sapatos, chapins, de meio pé de comprido, de prata. Tampouco saíam de portas afora para a rua, mesmo que fosse pelo espaço de meia pedrada, sem serem carregadas entre dois escravos numa rede de grande valor. E sobre ela, para guardá-la do sol, um pano de rico bordado engastado de pérolas. E à noitinha era moda banhar-se, quando já estava escuro, numa fonte feita para esse propósito, perto da qual havia passeio em seus jardins sombreados por laranjeiras e cidreiras; de modo que ela, vindo de refrescar-se, encontrava então, sob essas sombras, onde o próprio ar perfumado com o odor de frutas e flores, seu bem amado, que ali a esperava. A [dama], com um toque de sua viola ou de algum outro instrumento dava alarme ao peregrino, que com toda a diligência buscava essa emboscada. E achando-a, desafiava a outra facção que respondendo "amigo", descarregava-Ihe uma saraivada de abraços, ficando ela mesma prisioneira de sua mercê, cujo tenro coração lhe dá bom quartel e por razão de piedade a ela propicia tantos favores quantos pode fornecer suas forças. Até que a lua, ficando descoberta, começa a desalojar esses lugares e eles fogem para buscar algum outro refúgio seguro mais privado (NIEUHOF 1981, p. 15, 43-44).

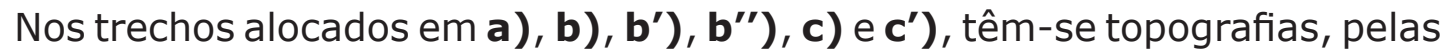
descrições de ilha, de "país", de cidade, sendo que, no $\mathbf{c}^{\prime}$ ), mobiliza-se também uma etopeia pela descrição de hábitos e costumes de pessoa, indicando caráter 
e disposição de ânimo. No a'), tem-se uma hipotipose, pela pintura de ações do herói Matias de Albuquerque. Esse exemplo, como ecfrase possivelmente deleita e agrada a recepção em virtude do lugar ameno que descreve, como pausa em meio à narração de ações bélicas, conforme fica visível na parte em que descreve e mostra os banhos no jardim, no colóquio entre amantes cuja relação é de vassalagem, como no amor cortês.

\section{Pintura do engenho e do juízo}

Da demonstração acima recolhe-se que a elocução do gênero histórico narrativo-discursivo de variantes história, anais, vidas, diários fabrica realidades narrativas por meio de descrições topográficas, prosopográficas, etopeicas, antropográficas; ecfrásicas, que amplificam e hipervalorizam o discurso patético em suas matérias graves, elevadas. As pinturas de história do primeiro grau do ornato não são idênticas nos subgêneros trabalhados. Nas histórias e nos anais, parecem variar mais e serem mobilizadas todas as espécies, enquanto que, nos diários, parecem ser dominantes as topografias. As vidas, por sua vez, demandam e empenham prosopografias, antropografias, etopeias e hipotiposes, sendo que as antropografias parecem ser mais abundantes quando se fabrica o encômio da vida dos heróis. As comparações, analogias, os epítetos substancializados, principalmente, e adjetivados, as metáforas, sinédoques, metonímias, alegorizadas ou não, as figuras patéticas, as enumerações, são ornatos que, em estilo historiográfico agudo, deleitam e instruem, apresentando as coisas com vivacidade aos olhos do receptor; como pintura, o estilo desses tipos de prosa constrói-se como juízo engenhoso, ou como engenhosidade judiciosa, em conveniente quiasma seiscentista, já que prosa didática. Lembro que, no século XVII, a analogia é conceitual, porque, como a pensam Gracián e Tesauro, funciona como base do pensamento agudo, veiculado por metáforas de semelhança, ou de proporção, ou de atribuição, possibilitando formar conceitos. Penso que no corpus discutido funcionem para permitir o encontro do humano com o divino de sua criação na história, seja católica, seja calvinista, guardadas suas diferenças salvíficas/remissoras, providencialistas/ predestinadas, misericordiosas/piedosas, uma vez que "análogo" ou "analogia" têm, no caso católico, sentidos tomistas de participação e, no caso calvinista, de eleição e predestinação para que se encenem as verdades dos discursos. Com esse conceito, letrados, de um modo geral, provam ou atestam de modos críveis e prestigiados seus discursos, fazendo do procedimento figura ou elocução que mimetiza raciocínios historiográficos, entre outros, uma vez que a analogia fundamenta e regula as representações.

Tanto a Igreja Católica quanto a Reformada calvinista não determinam os modos de fazer, nem os de fazer ver e crer, mas eles são mediados por moralizações. Pertencem a sistemas de hábitos, leis, políticas, éticas, costumes próprios do mundo em que são pensados e exercitados. Os discursos católicos, ibéricos, estudados fazem interpretações proféticas, enquanto os discursos calvinistas holandeses figuram uma história natural que é sombra, realização temporal sustentada via trabalho humano oferecido ao seu Criador. 
Para finalizar, é preciso dizer que, no destinatário ibérico das narrativas de gênero histórico, as interpretações do sentido do representado são, além disso, mediadas providencialmente pela metafísica da Luz Natural da Graça, pelo pacto de sujeição e eleição próprios da racionalidade de corte católica do Antigo Regime, que não se dispõe de tempo para examinar aqui, mas que pode ser definida como mediação teológico-político-retórica que visa ao aperfeiçoamento de excelências e à salvação. Por outro lado, o destinatário holandês interpreta as narrativas pelas doutrinas reformadas calvinistas, como a da predestinação. ${ }^{5}$

A história seiscentista se faz como pintura doutrinada pelo engenho e pelo juízo, porque respeita as prescrições epidíticas de variantes encomiásticas, cujas funções didáticas e deleitadoras são desempenhadas pelas técnicas demonstrativo-deliberativas de tirar ou extrair do natural (do testemunho) e pôr às vistas (aos olhos do espectador). Sua finalidade é a de fazer ver para saber fazer, ensinar a fazer para comover e mover o leitor/ouvinte/espectador e não apenas fornecer informações factuais.

\section{Referências bibliográficas}

ARISTÓTELES. Retórica. Tradução e notas de Manuel Alexandre Júnior, Paulo Farmhouse Alberto, Abel do Nascimento Pena. Introdução de Manuel Alexandre Júnior. Lisboa: Imprensa Nacional/Casa da Moeda, 1998.

Aristotelos peri Poietikes. Aristotelis Ars Poetica. Poética de

Aristóteles. Ed. trilíngue por Valentín García Yebra. Madrid: Gredos, 1974.

BARLÉU, Gaspar. História dos feitos recentemente praticados durante oito anos no Brasil e noutras partes sob o governo do ilustríssimo João Maurício Conde de Nassau etc., ora Governador de Wesel, Tenente-General de Cavalaria das Províncias-Unidas sob o Príncipe de Orange. Tradução e anotação de Cláudio Brandão. Prefácio e notas de Mário G. Ferri. Belo Horizonte; São Paulo: Itatiaia; EDUSP, 1974.

BOULAY, Bérenger. Effets de présence et effets de vérité dans I'historiographie. Littérature, n 159 (Écrire l'histoire), 2012. Disponível em: http:// www.fabula.org/atelier.php?Effets_de_presence\#_ftnref. Acessado em $17 / 11 / 2012$.

CALADO, Frei Manuel. O Valeroso Lucideno. Belo Horizonte, São Paulo: Itatiaia, Editora da Universidade de São Paulo, 1987.

COELHO, Duarte de Albuquerque. Memórias Diárias da Guerra do Brasil. Recife: Secretaria do Interior, 1944.

CUMMINS, Tom. De Bry and Herrera. Aguas Negras or the Hundred Years War over an Image of America. In: CURIEL Méndez, Gustavo; GONZÁLEZ Mello, Renato; GUTIÉRREZ Haces, Juana (Coord.) Arte, historia e identidad

\footnotetext{
${ }^{5}$ Cf., a propósito das diferenças entre historiografia católica e reformada, CUMMINS (1994).
} 
en América: visiones comparativas: XVII coloquio internacional de historia del arte. 1994. p. 17-32. Vol. 1.

FREIRE, Brito. Nova Lusitânia: História da Guerra Brasílica (1675). Recife:

Secretaria de Educação e Cultura, 1977.

GUINZGURG, Carlo. El Hilo y las Huellas. Buenos Aires: FCE, 2010.

GRACIÁN, Baltasar. Agudeza y Arte de Ingenio. Madri: Clássicos Castalia, 1987.

GUERREIRO, Bartolomeu. Jornada para se recuperar a cidade de Salvador (1625). Rio de Janeiro: Biblioteca Nacional, 1966. (Coleção Rodolfo Garcia).

HANSEN, João Adolfo. Categorias epiditícas da ekphrasis. Revista USP, Vol. 71, p. 85, 2007.

HORACIO. Art Poétique. In: . Oeuvres Complétes. Paris: Garnier, 1944.

LAET, Johannes. História ou anais dos feitos da Companhia Privilegiada das Índias Ocidentais (1644). Tradução de José Higino e Pedro Souto Maior. Anais da Biblioteca Nacional, vols. 30, 33, 38 e 41-42, 1912-1919/20.

MELO, Francisco Manuel de. Epanaphoras de Varia Historia Portvgveza. $3^{a}$ ed. revista e anotada por Edgar Prestage. Coimbra: Imprensa da Universidade, 1931.

MENESES, Luís de ( $3^{\circ}$ Conde da Ericeira). História de Portugal Restaurado.

Ed. anotada e prefaciada por Antônio Álvaro Dória. Rio de Janeiro: Civilização, 199? (2 Vols.).

MOREAU, Pierre. História das últimas lutas no Brasil entre holandeses e portugueses. Tradução e notas de Leda Boechat Rodrigues. São Paulo: EDUSP; Itatiaia, 1979.

NIEUHOF, Joan. Memorável viagem marítima e terrestre ao Brasil. Tradução de Moacir N. Vasconcelos. São Paulo: EDUSP/Itatiaia, 1981.

PUDSEY, Cuthbert. Diário de uma Estada no Brasil (1629-1640). Tradução de Nelson Papavero e Dante Martins Teixeira. Petrópolis: Index, 2000.

QUINTILIANO. Instituição Oratória. In: Oeuvres complètes de Quintilien. Paris: Garnier, 199?. (3 T.)

SANTIAGO, Diogo Lopes. História da guerra de Pernambuco. Recife: FUNDARPE, 1984.

SPINI, Giorgio. I trattatisti dell'arte storica nella Contrariforma italiana. Firenze: Quaderni di Belfagor, I, p. 109-137, 1948.

STRASBURGER, H. Die Wesensbestimmunng der Geschichte durch die antike Geschichtsschreibung. Wiesbaden, 1978.

TESAURO, Emanuele. II Cannocchiale Aristotélico ossia idea delle argutezze heroiche volgarmente chiamata impresse examinate infonte co' rettorici precetti del divino Aristotele, che comprendono tutta la Retorica e la Poética Elocuzione. Torino: Sinibaldo, 1670. 
VEGAS, Ferdinando. La concezione della storia dall'Umanesimo alla Contrariforma. Grande antologia filosofica. Milano: Marzorati, 1964. p. 1-59. (Vol. IX).

VIDAL, Silvina. El arte histórica en la España del siglo XVII: San José y el Genio de la Historia (1651). In: CASAZZA, Roberto et al. (ed.), Ciencias y letras en la América Colonial. Buenos Aires: Teseo, 2009. p. 137-147. 